\title{
Nutritional practices and postnatal growth restriction in preterm newborns
}

\author{
Adriana Martins de Lima ${ }^{1 *}$, Ana Lucia Goulart² ${ }^{2}$, Adriana Bruscato Bortoluzzo ${ }^{3}$, Benjamin Israel Kopelman ${ }^{4}$ \\ ${ }^{1} \mathrm{MSC}$ - Nutritionist of the Preterm Clinic of Universidade Federal de São Paulo (Unifesp), São Paulo, SP, Brazil \\ ${ }^{2}$ PhD - Adjunct Professor of Neonatal Pediatrics at the Pediatrics Department, Vice Head of the Pediatrics Department, Unifesp, São Paulo, SP, Brazil \\ ${ }^{3} \mathrm{PhD}$ - Assistant Professor of the Research Center at Intituto de Ensino e Pesquisa (Insper), São Paulo, SP, Brazil \\ ${ }^{4} \mathrm{PhD}$ - Retired Full Professor of Neonatal Pediatrics at the Pediatrics Department, Universidade Federal de São Paulo, São Paulo, SP, Brazi
}

\begin{abstract}
SUMMARY
Study conducted at Universidade Federal de São Paulo, São Paulo, SP, Brazil

Article received: $7 / 22 / 2014$ Accepted for publication: $8 / 24 / 2014$

*Correspondence: Address: Rua Diogo de Faria, 764 Vila Clementino São Paulo, SP - Brazil

Objective: to assess the nutritional practices in neonatal intensive care units (NICU) associated with growth retardation in premature (preterm) infants. Methods: retrospective study of preterm infants weighing between 500 and $1,499 \mathrm{~g}$ admitted to NICU. Evolution of growth and parenteral (PN) and enteral (EN) nutrition practices were analyzed.

Results: among 184 preterm infants divided into G1 (500 to 990g; $\mathrm{n}=63$ ) and G2 (1000 to $1499 \mathrm{~g} ; \mathrm{n}=121), 169$ received PN (G1=63, G2=106). Compared with the recommendations, $\mathrm{PN}$ was started late, its progress was slow and the maximum glucose, amino acid, lipid and energy supplies were low in both groups. The initial supply of amino acid and lipid and initial and maximum glucose and energy were lower in G1. The onset of EN was early (1-2 days), the time to reach exclusive EN was appropriate (11-15 days) and the use of human milk was possible in a reasonable amount of time (7-13 days). The multivariate analysis showed that respiratory distress syndrome and obtaining a supply of $120 \mathrm{kcal} / \mathrm{kg} / \mathrm{day}$ too late increased the chance of weight loss greater than $10 \%$. Sepsis, maximum energy supply for PN $<60 \mathrm{kcal} / \mathrm{kg} /$ day and obtaining a supply of $120 \mathrm{kcal} / \mathrm{kg} /$ day too late increased the chance of regaining birth weight after 14 days, while small for gestational age (SGA) at birth reduced this chance. SGA at birth, sepsis and achieving exclusive enteral nutrition after 14 days increased the chance of being SGA at post-conceptual age of term.

Conclusion: improving nutritional practices in the NICU can reduce the growth deficit in premature infants of very low birth weight.
\end{abstract} Postal code: 04037-002 dpneonatal@terra.com.br

http://dx.doi.org/10.1590/1806-9282.61.06.500
Keywords: premature, enteral nutrition, parenteral nutrition, very low birth weight.

\section{INTRODUCTION}

Postnatal growth is an important predictor of growth and development throughout childhood in preterm infants ${ }^{1-3}$ but despite knowing the importance of optimizing growth rates in the neonatal period, reducing the rate of extra-uterine growth restriction is still one of the great challenges for neonatal intensive care units (NICU). ${ }^{46}$ The difficulties in providing adequate nutritional support in the hospitalization phase $e^{7-11}$ of newborns with very low weight is one of the main reasons for this postnatal growth deficit.

A study to assess the nutritional practices adopted by four neonatal intensive care units, with different levels of complexity and dimensions, showed that after analysis and adaptation of the routines of each center to the recommendations established in the literature, there was a reduction in the number of days for starting parenteral and enteral nutrition, a shorter time for achieving exclusive enteral nutrition and an energy supply of $120 \mathrm{kcal} /$ $\mathrm{kg} /$ day, reduced length of hospital stay, and reduced percentage of children with weight below the $10^{\text {th }}$ percentile upon discharge. ${ }^{1}$

The objective of this study was to assess the nutritional practices in a NICU and their relationship to the growth of preterm newborns during hospitalization. 


\section{Methods}

This was a retrospective analysis of the medical records of premature infants born between January 2000 and December 2005 in a public teaching hospital. Preterm infants with birth weight (BW) between 500 and 1,499 g admitted to the neonatal intensive care unit at Hospital São Paulo were considered eligible. The exclusion criteria were death $\leq 7$ days, major congenital anomalies and genetic syndrome. The study was evaluated by the Ethics Committee of the Universidade Federal de São Paulo, which considered signing the informed consent form unnecessary.

The data included about the newborns were gestational age, sex, birth weight, small for gestational age (SGA) characterized as birth weight below the $10^{\text {th }}$ percentile (Alexander et al, 1996) ${ }^{12}$ and resuscitation in the delivery room. The morbidities analyzed were respiratory distress syndrome (RDS), sepsis, necrotizing enterocolitis (NEC), patent ductus arteriosus (PDA), peri-intraventricular hemorrhage (PIVH) grades III and IV, bronchopulmonary dysplasia (BPD) and frequency of SGA at post-conceptual age of term (weight below the $10^{\text {th }}$ percentile).

The drugs and procedures analyzed were use of surfactant, indomethacin, corticosteroids, mechanical ventilation and central venous catheter.

Bodyweight was recorded daily in accordance with the recommended standards. The maximum percentage of weight loss, time to regain birth weight, daily weight gain after recovery of birth weight and the number of days to reach 1800 grams were calculated.

Nutritional data were recorded daily and included the period between birth and a weight of $1800 \mathrm{~g}$. For parenteral nutrition (PN) the start date, duration, and maximum initial supply of glucose, protein, lipid and energy were collected. For enteral nutrition (EN), characterized by infusion of the diet via gastrostomy tube, the type of diet, start date and number of days of minimal enteral nutrition use ( $\leq 10 \mathrm{~mL} / \mathrm{kg} /$ day, without increments), days to achieve exclusive enteral nutrition and energy supply of $120 \mathrm{kcal} / \mathrm{kg} /$ day were recorded.

Nutritional therapy was prescribed by the attending physicians, according to routine of the neonatal intensive care unit during the study period. PN and EN should be initiated within the first 48 hours of life. The recommendations established for PN were $80 \mathrm{kcal} / \mathrm{kg} /$ day of energy, maximum initial supply of glucose $6 \mathrm{~g} / \mathrm{kg} /$ day and 16 to $18 \mathrm{~g} / \mathrm{kg} /$ day, respectively; amino acids and lipids starting within 48 hours of birth and initial doses, increments and maximum supply of $1.0,1.0$ and $3.5 \mathrm{~g} / \mathrm{kg} /$ day of amino ac- ids and 0.5 to $1.0 \mathrm{~g} / \mathrm{kg} /$ day, 0.5 to $1.0 \mathrm{~g} / \mathrm{kg} /$ day and $3.0 \mathrm{~g} /$ $\mathrm{kg} /$ day of lipids, respectively.

Minimal enteral nutrition could be initiated within the first 48 hours of life and the progression to exclusively enteral nutrition was performed according to the clinical status of the child, with increments of $20 \mathrm{~mL} / \mathrm{kg} /$ day in volume. Human milk was only to be used where possible, and formula for preterm infants when breast milk was not available. The use of additives to human milk started when human milk volume reached $100 \mathrm{~mL} / \mathrm{kg} /$ day.

The numerical variables were expressed as median and range, and compared using the Mann-Whitney $\mathrm{U}$ test, or the mean and standard deviation, compared using the Student's t test. The categorical variables were expressed as numbers and percentages, and compared using the chi-square or Fisher's exact test.

To assess the factors associated with the percentage of weight loss, time to regain birth weight and frequency of small children for post-conceptual age, a logistic regression model was created using the variables with $\mathrm{p}$ value $<0.15$. The statistical analysis was performed using Stata 10.0 software. Statistical significance was set at $5 \%(\mathrm{p}<0.05)$.

\section{ResULTS}

During the study period, 305 preterm infants with birth weights between 500 and 1,499 g were admitted to the NICU at Hospital São Paulo. One hundred and one of these were excluded: 87 for death $\leq 7$ days, 11 for major congenital malformations and 3 for not using PN and EN. Twenty medical records were not located, although some of the data was available. The study group and the group with incomplete information were similar according to the perinatal variables, but the use of central venous catheter was higher $(\mathrm{p}=0.001)$ in the group with incomplete information ( 7 vs. $37.5 \%$ ).

The 184 newborns were divided into two subgroups according to birth weight: group (G1) - 500 to $999 \mathrm{~g}$ $(\mathrm{n}=63)$ and group $(\mathrm{G} 2)-1,000$ to $1,499 \mathrm{~g}(\mathrm{n}=121)$. Except for gender, all clinical variables were different between subgroups (Table 1).

The infusion of glucose began within the first hours of life in all patients. PN was administered in 169 (92\%) newborns (63 in G1 and 106 in G2) and their characteristics are shown in Table 2.

The number of children receiving amino acids within the first 48 hours of life, between 48 and 72 hours and after 72 hours were, respectively, 36 (57.2\%), $14(22.2 \%)$ and $13(20.6 \%)$ in G1, and 54 (50.9\%), 31 (29.2\%) and 21 $(19.9 \%)$ in G2, while the ones receiving lipids in these periods were, respectively, 36 (57.2\%), 14 (22.2\%) and 13 
TABLE 1 Characteristics of the newborns in the hospitalization period.

\begin{tabular}{llll} 
& Group 1 (n=63) & Group 2 (n=121) & P \\
\hline Gestational age (weeks) & $27.7 \pm 2.1$ & $30.6 \pm 2.2$ & 0.000 \\
\hline Male & $25(39.7 \%)$ & $66(54.5 \%)$ & 0.055 \\
\hline Birth weight (g) & $798.2 \pm 142.4$ & $1258.3 \pm 137.1$ & 0.000 \\
\hline SGA & $13(20.6 \%)$ & $43(35.5 \%)$ & 0.037 \\
\hline Resuscitation in the delivery room & $53(84.0 \%)$ & $60(49.6 \%)$ & 0.000 \\
\hline RDS & $37(58.1 \%)$ & $35(28.9 \%)$ & 0.000 \\
\hline Sepsis & $48(76.1 \%)$ & $44(36.3 \%)$ & 0.000 \\
\hline Necrotizing enterocolitis & $12(19.0 \%)$ & $11(9.0 \%)$ & 0.053 \\
\hline Patent ductus arteriosus & $28(44.4 \%)$ & $25(20.6 \%)$ & 0.001 \\
\hline PIVH & $31(49.2 \%)$ & $20(16.5 \%)$ & 0.000 \\
\hline Bronchopulmonary dysplasia & $35(55.5 \%)$ & $16(13.2 \%)$ & 0.000 \\
\hline Surfactant & $34(53.9 \%)$ & $30(24.8 \%)$ & 0.000 \\
\hline Indomethacin & $24(38.1 \%)$ & $22(18.2 \%)$ & 0.003 \\
\hline Corticoid & $3(4.8 \%)$ & $3(1.6 \%)$ & 0.336 \\
\hline Central venous catheter & $42(66.7 \%)$ & $34(28.1 \%)$ & 0.000 \\
\hline Mechanical ventilation (hours) & $264(24-1032)$ & $120(12-1296)$ & 0.000 \\
\hline
\end{tabular}

SGA: small for gestational age; RDS: respiratory distress syndrome; PIVH: peri-intraventricular hemorrhage.

\section{TABLE 2 Characteristics of parenteral and enteral nutrition.}

Days to maximum supply

\begin{tabular}{|c|c|c|c|}
\hline Parenteral nutrition & Group $1(n=63)$ & Group $2(n=106)$ & $\mathrm{p}$ \\
\hline Glucose & $5(1-26)$ & $4(1-35)$ & 0.283 \\
\hline Amino acids & $7(2-33)$ & $6(2-31)$ & 0.106 \\
\hline Lipids & $6(2-31)$ & $7(2-38)$ & 0.085 \\
\hline Initial glucose (g/kg/day) & $5.8(1.5-10.0)$ & $7.3(0.3-11.5)$ & 0.000 \\
\hline Maximum glucose (g/kg/day) & $9.8(5.7-18.2)$ & $13.3(5.3-18.6)$ & 0.000 \\
\hline Initial amino acid (g/kg/day) & $0.5(0.5-1.5)$ & $1.0(0.5-2.0)$ & 0.002 \\
\hline Maximum amino acid $(\mathrm{g} / \mathrm{kg} /$ day $)$ & $2.0(0.5-3.5)$ & $2.0(0.5-4.0)$ & 0.967 \\
\hline Initial lipid (g/kg/day) & $0.5(0.5-1.0)$ & $0.5(0.5-1.5)$ & 0.001 \\
\hline Maximum lipid (g/kg/day) & $2.0(0.5-3.0)$ & $2.0(0.5-3.5)$ & 0.746 \\
\hline Initial energy ( $\mathrm{kcal} / \mathrm{kg} /$ day $)$ & $24.9(10.1-42.3)$ & $34.7(1.0-49.1)$ & 0.000 \\
\hline Maximum energy ( $\mathrm{kcal} / \mathrm{kg} /$ day) & $51.1(27.3-87.1)$ & $60.1(27.2-96.2)$ & 0.000 \\
\hline Start of PN (days) & $2(1-6)$ & $3(1-11)$ & 0.472 \\
\hline Duration of PN (days) & $11(2-104)$ & $8.5(1-68)$ & 0.006 \\
\hline Enteral Nutrition & Group $1(n=63)$ & Group 2 (n=121) & $\mathbf{p}$ \\
\hline Human milk (days) & $13(1-60)$ & $7(1-44)$ & 0.004 \\
\hline Human milk and Formula (days) & $14(1-97)$ & $9(1-46)$ & 0.002 \\
\hline Preterm formula (days) & $27(2-88)$ & $24(1-64)$ & 0.107 \\
\hline Start of EN (days) & $4(1-16)$ & $3(1-11)$ & 0.000 \\
\hline Duration of minimum EN (days) & $2(1-30)$ & $1(1-15)$ & 0.000 \\
\hline Time for exclusive EN (days) & $15(3-42)$ & $11(5-69)$ & 0.001 \\
\hline Duration of EN (days) & $44(1-95)$ & $23.5(7-76)$ & 0.000 \\
\hline Time to $120 \mathrm{kcal} / \mathrm{kg} /$ day (days) & $22(10-52)$ & $15(7-63)$ & 0.000 \\
\hline
\end{tabular}

$\mathrm{PN}$ : parenteral nutrition; EN: enteral nutrition. 
(20.6\%), in G1, and 49 (46.2\%), 35 (33.0\%) and 22 (20.8\%), in $\mathrm{G} 2$, both without statistically significant differences. The duration of PN was longer ( $\mathrm{p}=0.006)$ in $\mathrm{G} 1$ compared to G2. There was a significant difference between the groups for most of the EN variables (Table 2). Seven children (11.1\%) in G1 and 3 children in G2 (2.5\%) did not receive human milk $(\mathrm{p}=0.002)$.

Most variables related to neonatal growth were different between the groups. The percentage of weight loss was greater $(\mathrm{p}=0.009)$ in $\mathrm{G} 1(13.4 \% ; 0.4$ to $44.7 \%)$ than in G2 (10.0\%; 0.7 to $23.3 \%)$, the time to regain birth weight was longer $(\mathrm{p}=0.005)$ in $\mathrm{G} 1(17.7,9.5$ days $)$ compared to G2 (12.9, 6.0 days) and the average daily gain was lower $(\mathrm{p}=0.000)$ in $\mathrm{G} 1(20.5,0.8 \mathrm{~g})$ compared to $\mathrm{G} 2(25.7,2.5 \mathrm{~g})$. The time to reach $1800 \mathrm{~g}$ was longer $(\mathrm{p}=0.000)$ in the extremely low birth weight at birth group (46 days; 9 to 81 vs. 21 days; 9 to 25). The frequency of SGA infants at postconceptual age of term was higher in G1, 52 (82.5\%) vs. $88(72.7 \%)$, but without statistical significance $(\mathrm{p}=0.139)$.

To assess the factors associated with maximum weight loss greater than $10 \%$ of birth weight, time to regain birth weight greater than 14 days and frequency of SGA at post-conceptual age of term, the logistic regression model included gender, birth weight, SGA at birth, respiratory distress syndrome, sepsis, necrotizing enterocolitis, mechanical ventilation $>7$ days, use of $\mathrm{PN}>8$ days, maximum glucose supply $<16.0 \mathrm{~g} / \mathrm{kg} /$ day, maximum a mino acid supply $<2.0 \mathrm{~g} / \mathrm{kg} / \mathrm{day}$, maximum lipid $<2.0 \mathrm{~g} / \mathrm{kg} /$ day and energy supply $<60 \mathrm{kcal} / \mathrm{kg} /$ day and time to achieve exclusive EN and energy supply of $120 \mathrm{kcal} / \mathrm{kg} / \mathrm{day}$ by EN for more than 14 days. The results are presented in Table 3 .

\section{Discussion}

With the increase in the survival of newborns with very low weight, reduction of morbidities and improved prognosis in the long term have become priorities. As such, neonatal nutrition is essential for adequate growth and development of preterm newborns.

According to recent recommendations, $\mathrm{PN}$ can be initiated within the first hours of life, and is safe and effective even in very premature infants. ${ }^{13-15}$ In this study, PN was administered to $92 \%$ of newborns, but only $50 \%$ started it within the first 48 hours of life. Glucose administration was performed early, with an appropriate initial supply, ${ }^{16,17}$ and although the duration of $\mathrm{PN}$ was sufficient, the maximum supply achieved was lower than recommended. The incidence of hyperglycemia is high in extremely premature infants and may limit the administration of glucose in these newborns. ${ }^{18}$
TABLE 3 Final logistic regression model to assess the relationship between clinical and nutritional variables and growth variables.

$$
\text { OR } \quad 95 \mathrm{Cl}
$$

p

\section{Weight loss $>10 \%$ of}

birth weight

\begin{tabular}{llll}
\hline Respiratory distress syndrome & 3.024 & {$[1.385 ; 6.605]$} & 0.005 \\
\hline$>14$ days to $120 \mathrm{kcal} / \mathrm{kg} /$ day & 3.442 & {$[1.517 ; 7.719]$} & 0.030 \\
\hline$>14$ days to regain birth weight & & & \\
\hline $\mathrm{SGA}$ & 0.302 & {$[0.127 ; 0.717]$} & 0.007 \\
\hline Sepsis & 2.636 & {$[1.254 ; 5.540]$} & 0.010 \\
\hline $\begin{array}{l}\text { Maximum energy via } \mathrm{PN}<60 \\
\mathrm{kcal} / \mathrm{kg} / \text { day }\end{array}$ & 3.029 & {$[1.425 ; 6.442]$} & 0.004 \\
\hline$>14$ days to $120 \mathrm{kcal} / \mathrm{kg} /$ day & 4.551 & {$[1.753 ; 11.814]$} & 0.001 \\
\hline
\end{tabular}

\section{Small for post-conceptual}

age of term

\begin{tabular}{lllll}
\hline SGA at birth & 9.995 & {$[2.134 ; 46.826]$} & 0.004 \\
\hline
\end{tabular}

\begin{tabular}{lllll}
\hline Sepsis & 4.253 & {$[1.496 ; 12.087]$} & 0.006 \\
\hline
\end{tabular}

$\begin{array}{lllll}>14 \text { days for exclusive } \mathrm{EN} & 6.994 & {[2.174 ; 22.501]} & 0.001\end{array}$

PN: parenteral nutrition; EN: enteral nutrition.

The infusion of glucose with amino acids on the first day of life decreases protein catabolism, increases protein incorporation rates, can help lower plasma glucose concentrations and should be started within the first days of life. ${ }^{17,19}$ Studies comparing a high versus low supply of amino acids in the first days of life showed that high protein supplies resulted in increased protein incorporation without increasing toxicity, ${ }^{20-26}$ with initial supplies of $3.0 \mathrm{~g} /$ $\mathrm{kg} /$ day being recommended. In our study, only $53 \%$ received amino acids in the first 48 hours of life, and the initial and maximum supplies were low, taking 6 to 7 days to reach the maximum supply. This practice exposed newborns to a negative protein balance and may have contributed to the low supply of glucose and energy.

Lipid emulsions are fundamental in PN for preterm newborns to meet the energy requirements for maintenance and growth and to prevent a deficiency of essential fatty acids. Lipid administration strategies include a minimum supply of 0.5 to $1.0 \mathrm{~g} / \mathrm{kg} / \mathrm{day}$, starting on the first day of life, increasing 0.5 to $1.0 \mathrm{~g} / \mathrm{kg}$ day to a maximum of $3.0 \mathrm{~g} / \mathrm{kg} /$ day, attained in 4 to 5 days. ${ }^{15,16,27,28}$ In this study, approximately $50 \%$ of patients received lipid emulsion after 48 hours of life, the initial and maximum doses were low and it took 6 to 7 days to reach the maximum dose. This lipid supply was sufficient to meet the essential fatty acid requirements, but contributed to the low supply of energy. This conservative approach may have been the result of concerns with toxicity. However, a me- 
ta-analysis showed no differences between groups who received an early supply and those who did not receive an early supply of lipids in terms of growth, death and chronic lung disease outcomes. ${ }^{29}$

In the present study, EN was in line with the recommendations for best practices. ${ }^{30}$ Minimum EN was started early, its duration was short and the progression to exclusive EN was quick. EN in newborns of very low birth weight is often delayed for several days or weeks after birth, due to cardiorespiratory complications and concern about necrotizing enterocolitis. ${ }^{31}$ However, minimal enteral nutrition, especially human milk, provides numerous benefits and has been associated with a shorter time to reach exclusive EN, as well as reduced infection associated with central venous catheter, without increasing the incidence of necrotizing enterocolitis. ${ }^{32}$

The proposed increment of $20 \mathrm{~mL} / \mathrm{kg} /$ day for $\mathrm{EN}$ is considered safe according to studies showing that increments of up to $30 \mathrm{~mL} / \mathrm{kg} /$ day were not associated with increased incidence of necrotizing enterocolitis. ${ }^{33}$ With the increase in volume adopted, the time to achieve exclusive enteral nutrition was appropriate.

The frequency of interruptions in EN was high (29.9\%), but similar to those observed by Caple et al. of 26.8 and $29.6 \%$ for infants with low birth weight with increases in volume of 20 to $30 \mathrm{~mL} / \mathrm{kg} /$ day, respectively. ${ }^{33}$ The diagnosis of necrotizing enterocolitis was frequent in this study (12.5\%). The use of human milk was common, especially among newborns of extremely low birth weight, and may be a protective factor for enterocolitis; ${ }^{34,35}$ however, the mother's own milk or that from a donor was always pasteurized, which may have compromised its immunological capacity. ${ }^{36}$ In addition to stimulating the use of raw human milk from the actual mother, we should pay attention to some aspects of routine EN. As observed by Henderson et al., a shorter duration of minimal enteral nutrition and greater speed for attaining exclusive EN may be modifiable risk factors for the development of necrotizing enterocolitis. ${ }^{37}$

On the other hand, the time to reach $120 \mathrm{kcal} / \mathrm{kg} /$ day was long and may be related to the high frequency of feeding interruptions and diagnosis of necrotizing enterocolitis. The delay in attaining this energy supply was associated with greater weight loss and longer time to regain birth weight..$^{38}$ The delay in regaining birth weight was also associated with low energy supply via $\mathrm{PN}$, and the time to regain birth weight is a significant predictor of poor postnatal growth. ${ }^{39}$ The low energy supply via PN and the delay in achieving the maximum recommended supply in this population may be markers of an accumu- lated energy deficit and explain the higher percentage of weight loss and slower weight gain. ${ }^{40,41}$

Logistic regression analysis also showed that respiratory distress syndrome is associated with increased weight loss, which may be secondary to an inadequate supply of nutrients; this is especially difficult in children with respiratory failure. ${ }^{42}$ Sepsis increased the risk of delayed recovery of birth weight, and has been associated with slower weight gain during hospitalization; ${ }^{43}$ newborns with sepsis may develop intolerance to glucose and lipids, limiting the supply of these nutrients. As described by other researchers, ${ }^{43,44}$ SGA infants recovered their birth weight earlier. In this study, the SGA preterm infants had a greater gestational age than those of suitable weight for age (27.7 vs. 30.6 weeks) and may have presented a lower frequency of conditions that interfere with nutritional therapy.

The restriction of intrauterine growth is extremely common in children with very low birth weight. ${ }^{6,14,44,45} \mathrm{In}$ our population, the frequency of newborns with weight below the $10^{\text {th }}$ percentile for age increased from $30.4 \%$ at birth to $76.1 \%$ at post-conceptual age of term, and the associated factors were SGA, sepsis and higher time for attaining exclusive enteral nutrition. The association between restriction of extra-uterine growth, SGA, bronchopulmonary dysplasia, number of days of parenteral nutrition and age to attain exclusive enteral nutrition has also been shown in other studies. ${ }^{6,40-42}$

Nutritional practices for preterm infants vary considerably between NICU and there is no definite strategy with proven capacity to safely optimize nutrition, growth and development. ${ }^{10}$ However, the implementation of a program with potentially better nutritional practices can promote a more adequate supply of nutrients and stimulate growth. ${ }^{9}$

\section{Resumo}

Práticas nutricionais e restrição de crescimento pós-natal em prematuros

Objetivo: avaliar as práticas nutricionais em unidade de cuidados intensivos neonatais (UCIN) associadas a déficit de crescimento em recém-nascidos pré-termo (RNPT). Métodos: estudo retrospectivo de RNPT com peso entre 500 e $1.499 \mathrm{~g}$ internados em UCIN. Analisaram-se: evolução do crescimento e práticas de nutrição parenteral (NP) e enteral (NE).

Resultados: dentre 184 RNPT divididos em G1 (500 a $990 \mathrm{~g} ; \mathrm{n}=63)$ e G2 (1.000 a $1.499 \mathrm{~g} ; \mathrm{n}=121), 169$ receberam NP (G1=63; G2=106). Comparando-se com as reco- 
mendações, a NP foi iniciada tardiamente, sua progressão foi lenta e as ofertas máximas de glicose, aminoácidos, lipídios e energia foram baixas nos dois grupos. A oferta inicial de aminoácido e lipídio e a inicial e máxima de glicose e energia foram menores no G1. O início da NE foi precoce ( 1 a 2 dias), o tempo para atingir NE exclusiva foi adequado (11 a 15 dias), e o uso de leite humano foi possível por tempo razoável (7 a 13 dias). A análise multivariada mostrou que a síndrome do desconforto respiratório e o alcance tardio da oferta de $120 \mathrm{kcal} / \mathrm{kg} / \mathrm{dia}$ aumentaram a chance de perda de peso superior a $10 \%$. Sepse, oferta energética máxima por NP $<60 \mathrm{kcal} / \mathrm{kg} / \mathrm{dia}$ e alcance tardio da oferta de $120 \mathrm{kcal} / \mathrm{kg} /$ dia aumentaram a chance de recuperar o peso de nascimento após 14 dias, enquanto a condição de pequeno para idade gestacional (PIG) ao nascimento reduziu essa chance. PIG ao nascimento, sepse e alcance de NE exclusiva após 14 dias aumentaram a chance de ser PIG na idade pós-conceptual de termo.

Conclusão: aprimorar as práticas nutricionais em UCIN pode reduzir o déficit de crescimento em prematuros de muito baixo peso ao nascer.

Palavras-chave: prematuro, nutrição enteral, nutrição parenteral, recém-nascido de muito baixo peso.

\section{References}

1. Relly B, Duenas M, Greecher C, Kimberlim L, Mujsce D, Miller D, et al. Evaluation, development, and implementation of potentially better practices in neonatal intensive care nutrition. Pediatrics. 2003; 111(4):461-70.

2. Olsen IE, Douglas KR, Schimid CH, Ausman LM, Dwyer JT. Intensive differences in weight growth velocity of extremely premature infants. Pediatrics. 2002; 110(6):1125-31.

3. Ehrenkranz RA. Growth outcomes of very low-birth weight infants in the newborn intensive care unit. Clin Perinatol. 2000; 27(2):325-45.

4. Premer DM, Georgieff MK. Nutrition for ill neonates. Pediatr Rev. 1999; 20(9):56-62.

5. Stark AR, Carlo WA, Tyson JE, Papile LA, Wright LL, Shankaran S, et al. Adverse effects of early dexamethasone in extremely-low-birth-weight infants. National Institute of Child Health and Human Development Neonatal Research Network. N Engl J Med. 2001; 344(2):95-101.

6. Sakurai M, Itabashi K, Sato Y, Hibino S, Mizuno K. Extrauterine growth restriction in preterm infants of gestational age $<32$ weeks. Pediatr Int. 2008; 50(1):70-5.

7. Guzmán JM, Jaraba MJ, De La Torre MD, Ruiz-Conzález MD, Huertas RA, et al. Parenteral nutrition and immature neonates comparative study of neonates weighing under 1000 and $1000-1250$ g at birth. Early Hum Dev. 2001; 65 suppl:s133-s144.

8. Fanaroff AA, Stoll BJ, Wright LL, Carlo WA, Ehrenkranz RA, Stark AR, et al. Trends in neonatal morbidity and mortality for very low birthweight infants. Am J Obstet Gynecol. 2007; 196(2):1-8.

9. Hans DM, Pylipow M, Long JD, Thurren PJ, Georgieff MK. Nutritional practices in the neonatal intensive care unit: analysis of a 2006 neonatal nutrition survey. Pediatrics. 2009; 123(1):51-7.

10. Grover A, Khashu M, Mukherjee A, Kairamkonda V. Iatrogenic malnutrition in neonatal intensive care units: urgent need to modify practice. J Parenter Enteral Nutr. 2008; 32(2):140-4

11. American Academy of Pediatrics Committee on Nutrition: nutricional needs of low birth weight infants. Pediatrics. 1985; 75:976-86.
12. Alexander GR, Himes JH, Kaufman RB, Mor J, Kogan M. A United States National Reference for Fetal Growth. Obstet Gynecol. 1996; 87(2):163-8.

13. Koletzko B, Goulet O, Hunt J, Krohn k, Shamir R. Guidelines on paediatric parenteral nutrition of the European Society of Paediatric Gastroenterology, Hepatology and Nutrition (ESPGHAN) and European Society for Clinical Nutrition and Metabolism (ESPEN), support by the European Society of Paediatric Research (ESPR). J Paediatr Gastroenterol Nutr. 2005; 41(Suppl 2):S19-S27.

14. De Curtis M, Rigo J. Extrauterine growth restriction in very-low-birthweight infants. Acta Paediatr. 2004; 93(12):1563-8.

15. Ibrahim HM, Jeroudi MA, Baier RJ, Dhanireddy R, Krouskop RW. Aggressive early total parenteral nutrition in low-birth-weight infants. J Perinatol. 2004; 24(8):482-6.

16. Thureen PJ. Early aggressive nutrition in the neonate. Pediatr Rev. 1999; 20(9):45-55.

17. Parimi $\mathrm{P}, \mathrm{S}$ Kalhan. Carbohydrates including oligosaccharides and inositol. In: Tsang RC, Uauy R, Koletzko B, Zlotkin SH. Nutrition of the preterm infant. 2.ed. Digital Educational Publishing: Ohio, 2005. p.81-90.

18. Hays SP,Smith EO, Sunehag AL. Hiperglycemia is a risk factor for early death and morbidity in extremely low birth-weight infants. Pediatrics. 2006; 118 (5):1811-8

19. Thureen PJ, Anderson AH, Baron KA, Melara DJ, Hay WW, Fennessey PV. Protein balance in the first week of life in ventilated neonates receiving parenteral nutrition. Am J Clin Nutr. 1998; 68:1228-1136.

20. Thurren PJ, Heird WC. Protein requirement of the preterm/low birthweight (LBW) infant. Pediatric Research. 2005; 57(5):95-8.

21. Braake FWJ, van den Akker CHP, Wattimena DJL, Huijmans JGM, van Goudoever JB. Amino acid administration to premature infants directly after birth. J Pediatr. 2005; 147:457-61.

22. Van Den Akker CHP, Te Braake FWJ, Wattimena DJL, Voortman G, Schierbeek $\mathrm{H}$,Vermes A, et al. Effects of early amino acid administration on leucine and glucose kinetics in premature infants. Pediatr Res. 2006; 59(5):732-5.

23. Poindexter BB, Langer JC, Disick AM, Ehrenkranz RE. Early provision of parenteral amino acids in extremely low birth-weight infants: relation to growth and neurodevelopmental outcome. J Pediatr. 2006; 148(3):300-5.

24. Embleton ND. Optimal protein and energy intakes in preterm infants. Early Hum Dev. 2007; 83(12):831-7.

25. Jadhav P, Parimi PS, Kalhan SC. Parenteral amino acid and metabolic acidosis in premature infants. J Parenter Enter Nutr. 2007; 31(4):278-83.

26. Valentine CJ, Rogers SF, Gulati P, Hayes J, Lore P, Puthoff T, et al. Early amino-acid administration improves preterm infant weight. J Perinatol. 2009; 29(6):428-32

27. Koletzko B, Innis SM. Lipids. In: Tsang RC, Uauy R, Koletzko B, Zlotkin $\mathrm{SH}$. Nutrition of the preterm infant. 2.ed. Digital Educational Publishing: Ohio, 2005. p.97-127.

28. Ziegler EE, Thureen PJ, Carlson SJ. Aggressive nutrition of the very low birthweight infant. Clin Perinatol. 2002; 29(2):225-44.

29. Simmer K, Rao SC. Early introduction of lipids to parenterally-fed preterm infants. Cochrane Database Syst Rev. 2005:CD005256.

30. Ehrenkranz RA. Early, aggressive nutritional management for very low birth weight infants: what's is the evidence? Semin Perinatol 2007; 31(2):48-55.

31. Tyson JE, Kennedy KA, Lucke JF, Pedroza C. Dilemmas initiating enteral feedings in high risk infants: how can they be resolved? Semin Perintal. 2007; 31(2):61-73.

32. Kennedy KA, Tyson JE, Chamnanvanakij S. Rapid versus slow rate of advancement of feeding for promoting growth and preventing necrotizing enterocolitis in parenterally fed low birth weight infants. Cochrane Database Syst Rev. 2000:CD001241.

33. Caple J, Armentrout D, Huseby V, Halbardier B, Garcia J, Sparks JW, et al. Randomized, controlled trial of slow versus feeding volume advancement in preterm infants. Pediatrics 2004; 114(6):1597-600.

34. Yu VYH, Simmer K. Enteral nutrition: aspects, strategy and management. In: Tsang RC, Uauy R, Koletzko B, Zlotkin SH. Nutrition of the preterm infant 2.ed. Digital Educational Publishing: Ohio, 2005. p.311-22.

35. Sullivan S, Schanler RJ, Kim JH, Patel AL, Trawoger R, Kiechl-Kohlendorfer $\mathrm{U}$, et al. An exclusively human milk-based diet is associated with a lower rate of necrotizing enterocolitis than a diet of human milk and bovine milkbased products. J Pediatr. 2010; 156:562-7.

36. Schanler RJ, Lau C, Hust NM, Smith EO. Radomized trial of donor human milk versus preterm formula as substitutes for mother's own milk in the feeding of extremely premature infants. Pediatrics. 2005; 116(2):400-6.

37. Henderson G. Craig S, Brocklehurst P, McGuire W. Enteral feeding regimens and necrotizing enterocolitis in preterm infants: a multicentre case-control study. Arch Dis Child Fetal Neonatal. 2009; 94(2):120-3. 
38. Diekmann M, Genzel-Boroviczény O, Zoppelli L, von Poblotzki M. Postnatal growth curves for extremely low birth weight infants with early enteral nutrition. Eur J Pediatr. 2005; 164(12):714-23.

39. Yu VYH, Simmer K. Enteral nutrition: aspects, strategy and management In: Tsang RC, Uauy R, Koletzko B, Zlotkin SH. Nutrition of the preterm infant 2.ed. Digital Educational Publishing: Ohio, 2005. p.311-22.

40. Tyson JE, Kennedy KA, Lucke JF, Pedroza C. Dilemmas initiating enteral feedings in high risk infants: How can they be resolved? Semin Perintal. 2007; 31(2):61-73.

41. Radmacher PG, Looney SW, Rafail ST, Adamkin DH. Prediction of extrauterine growth retardation (EUGR) in VVLBW infants. J Perinatol. $2003 ; 23(5): 392-5$.
42. Clark RH, Thomas P, Peabody J. Extrauterine growth restriction remains a serious problem in prematurely born neonates. Pediatrics. 2003; 111(5):98690.

43. Ehrenkranz RA, Younes N, Lemons JA, Fanaroff AA, Donovan EF, Wright LL, et al. Longitudinal growth of hospitalized very low birth weight infants. Pediatrics. 1999; 104(2):280-9.

44. Embleton NE, Pang N, Cooke RJ. Postnatal malnutrition and growth retardation: an inevitable consequence of current recommendations in preterm infants? Pediatrics. 2001; 107(2):270-3.

45. Shan HM, Cai W, Cao Y, Fang BH. Extrauterine growth retardation in premature infants in Shanghai: a multicenter retrospective review. Eur J Pediatr. 2009; 168(9):1055-9. 